\section{Biotech offers Africans a chance to create their own practical solutions}

Sir-Agricultural biotechnology research and development (R\&D) in industrialized countries is heavily supported by private and government institutions and universities, which develop products and services for capital-intensive farming systems. Although some innovations have spill-over effects that might benefit Africa (especially large-scale farmers), most are likely to marginalize poor farmers.

One solution is to reorient international biotechnology research to take account of small-scale farmers' needs. But experience shows that this option is unlikely to succeed in the long term.

A more realistic way forward is for African scientists, businesses and farmers to devise biotechnological innovations that are appropriate to local cultural, economic, political, technological, institutional, infrastructural and social factors.

The success story of Africa Online, the premier provider of Internet services throughout Africa, illustrates an entrepreneurial spirit that should be possible to replicate in the biotechnology arena. Africa Online was founded in 1994 by three Kenyans studying at the Massachusetts Institute of Technology and Harvard University. It now serves thousands of people and businesses throughout Africa.

Private-sector companies wishing to invest in biotechnology are attracted by successes in tissue-culture-aided production and multiplication of diseasefree planting materials for cassava, yam, banana, plantain, citrus and flowers in countries such as Kenya and Ghana. However, Africans must learn simple technologies that are not only appropriate and feasible, but also sustainable.

Priority can be given to biotechnologies that have worked under comparable conditions elsewhere. Last year, for example, thousands of poor Chinese farmers obtained up to $40 \%$ increases in sweet-potato yields by using a novel seedproduction technique to eliminate viral diseases from planting materials (http://www.futureharvest.org/growth/ china_sweet.bkgnd.shtml). No genetic improvements were made, and the farmers used no more fertilizers or pesticides than usual.

In Africa, the key players will include, among others, scientists, policy-makers, non-governmental organizations, farmers and farmers' (especially women's) groups. Private biotechnology initiatives must go hand in hand with development of regulatory frameworks and public- awareness campaigns, and with other R\&D programmes targeting poor farmers (see, for example, F. Wambugu, Nature 400, 15-16; 2001)).

The mistake of the Green Revolution was that it treated all the world as if it were the same. The lesson for agriculture is that problems must be solved locally and communally, through a bottom-up approach that empowers farmers to support and own technologies that benefit them. Entrepreneurial scientists, businesspeople, lawyers and farmers are needed to explore the promises of biotechnology.

This is a wake-up call for African biotechnology stakeholders to transform the potential wealth of genetic resources and traditional knowledge into the reality of increased incomes - and better food and health care - for the majority. Jesse Machuka

Biotechnology Laboratory, International Institute of Tropical Agriculture, PMB 5320, Ibadan, Nigeria

\section{Kansas science saved by teachers' good sense}

Sir - The News in Brief report "Evolution allowed back into Kansas schools" (Nature $409,973 ; 2001)$ is not entirely accurate. In 1999, the Kansas Board of Education approved ill-advised science standards that did not include several key scientific principles, including macroevolution and the Big Bang.

However, contrary to many reports in the popular press over the past two years, the board does not have the power to direct schools to teach anything. The function of the standards is only to set the guidelines used in state-wide standardized testing, and they are used by teachers as a guide to help prepare their curricula.

Thanks to the good sense of Kansas teachers, the teaching of evolution was not left out of the curriculum in schools during the year these unfortunate and controversial standards were in effect. In fact, some anecdotal evidence suggests that evolution has been emphasized more than ever in Kansas schools since then.

The assertion in your News report that "creationists ... briefly had the Bible's account of the beginning of the world taught instead" is untrue. There was never any mention of the biblical account of creation in the controversial standards, and there have been no reports that creation was taught as part of any public school science curriculum in Kansas.

The News report correctly states that the citizens of Kansas have rectified the situation by defeating several of the antievolution board members in last year's elections, and that new science standards are now in place that include the aforementioned key scientific principles. Rollie J. Clem

Division of Biology, 307 Ackert Hall, Kansas State University, Manhattan, Kansas 66506, USA

\section{Bright light of learning snuffed out in Breslau}

Sir — Vaclav Smil's delightful Millennium Essay "Genius loci” (Nature 409, 21; 2001) emphasizes the importance of Budapest in twentieth-century science. I would like to propose Breslau, Germany (now Wroclaw, Poland), as another locus in central Europe. All the following scientists were born or grew up in Breslau: Max Born (Nobel Prize in Physics, 1954), Richard Courant (mathematician, 1888-1972), Paul Ehrlich (Nobel Prize in Physiology or Medicine, 1908), Fritz Haber (Nobel Prize in Chemistry, 1918), Reinhard Selten (Nobel Prize in Economic Sciences, 1994), Otto Stern (Nobel Prize in Physics, 1943) and Otto Toeplitz (mathematician, 1881-1940).

The scientific glory of the city is now lost. All in the above list were of Jewish descent and most were forced to leave Germany during the Nazi period. During and after the Second World War, the entire composition of the city changed.

Reinhard Selten in his Nobel prize autobiographical sketch (see http://www. nobel.se/economics/laureates/1994/ selten-autobio.html) says, "I have never visited Wroclaw since the war. Heavy fighting destroyed most of the town in which I grew up and most of the familiar places of my youth look different now." Min-Liang Wong

Department of Veterinary Medicine, College of Veterinary Medicine, National Chung-Hsing University, Taichung 402, Taiwan

\section{New information on the biodiversity facility}

Sir - Your otherwise interesting News report (Nature 410, 290; 2001) on the new Global Biodiversity Information Facility (GBIF — see http://www.gbif.org) contains some errors. GBIF, which came into being on 1 March this year, was not launched in Brussels. The first meeting of the GBIF governing board took place on 9-11 March in Montreal, Canada. Martin Sharman and Carlos Martinez-Riera are scientific officers at the European

Commission; they do not work for GBIF. Christoph L. Häuser

(Chair, GBIF Governing Board)

State Museum of Natural History,

Rosenstein 1, D-70191 Stuttgart, Germany 